\title{
Description of a New Species of the Genus Leptobrachella (Amphibia, Anura, Megophryidae) from Borneo
}

$\operatorname{AUTHOR}(\mathrm{S})$ :

Eto, Koshiro; Matsui, Masafumi; Nishikawa, Kanto

\section{CITATION:}

Eto, Koshiro ...[et al]. Description of a New Species of the Genus Leptobrachella

(Amphibia, Anura, Megophryidae) from Borneo. Current Herpetology 2015, 34(2): 128-139

\section{ISSUE DATE:}

2015-08

URL:

http://hdl.handle.net/2433/202518

\section{RIGHT:}

(c) 2015 by The Herpetological Society of Japan; The full-text file will be made open to the public on 1 September 2018 in accordance with publisher's 'Terms and Conditions for Self-Archiving'. 


\title{
Description of a New Species of the Genus Leptobrachella (Amphibia, Anura, Megophryidae) from Borneo
}

\author{
Author(s): Koshiro Eto, Masafumi Matsui and Kanto Nishikawa \\ Source: Current Herpetology, 34(2):128-139. \\ Published By: The Herpetological Society of Japan \\ DOI: http://dx.doi.org/10.5358/hsj.34.128 \\ URL: http://www.bioone.org/doi/full/10.5358/hsj.34.128
}

BioOne (www.bioone.org) is a nonprofit, online aggregation of core research in the biological, ecological, and environmental sciences. BioOne provides a sustainable online platform for over 170 journals and books published by nonprofit societies, associations, museums, institutions, and presses.

Your use of this PDF, the BioOne Web site, and all posted and associated content indicates your acceptance of BioOne's Terms of Use, available at www.bioone.org/page/terms_of_use.

Usage of BioOne content is strictly limited to personal, educational, and non-commercial use. Commercial inquiries or rights and permissions requests should be directed to the individual publisher as copyright holder. 


\title{
Description of a New Species of the Genus Leptobrachella (Amphibia, Anura, Megophryidae) from Borneo
}

\author{
Koshiro ETO*, Masafumi MATSUI, AND Kanto NISHIKAWA \\ Graduate School of Human and Environmental Studies, Kyoto University, Yoshida \\ Nihonmatsu-cho, Sakyo-ku, Kyoto 606-8501, JAPAN
}

\begin{abstract}
We describe a tiny megophryid frog Leptobrachella juliandringi sp. nov. from Northeastern to Central Sarawak, Malaysian Borneo. This species is distributed in hilly and montane regions, and has long been confused with L. mjobergi. Based on the assessment using morphological and bioacoustic approaches, we conclude that the new species is distinct from all the other congeneric species including topotypic $L$. mjobergi from western Sarawak in possessing a series of elongate glands ventrolaterally on the trunk, broken reticulated marking on the ventrum, strap-like lineae masculinae, and an advertisement call with a chirp. The new species is also differentiated phylogenetically from the other congeners, and tends to form a group with true $L$. mjobergi but with a large genetic divergence.
\end{abstract}

Key words: New species; MtDNA; Phylogeny; Leptobrachella mjobergi; Borneo; Taxonomy

\section{INTRODUCTION}

A Southeast Asian megophryid genus Leptobrachella Smith, 1925 is endemic to Borneo and the Natuna Islands, and its members are distinguished by their small adult body size, arrow-like projections on digital tips, and unique larval morphology (Inger, 1966; Malkmus et al., 2002). This genus was thought to include three species (L. mjobergi Smith, 1925, L. baluensis Smith, 1931, and L. natunae [Günther, 1895]) until Dring (1983) described L. brevicrus, L. parva, and L. serasanae, and Inger and Stuebing (1992) added $L$. palmata. No taxonomic study has

* Corresponding author. Tel: +81-75-753-2890; Fax: +81-75-753-6846;

E-mail address: koshiro.eto@gmail.com been conducted since then, but in view of the recent finding of many cryptic amphibian taxa in this region including another megophryid genus, Leptolalax (Dehling and Matsui, 2013; Matsui et al., 2014a, b), taxonomic reassessment of this genus is strongly required.

Leptobrachella mjobergi is the type species of the genus (Smith, 1925), and was thought to occur widely in Southwestern to Northern Sarawak and West Kalimantan of Borneo (Dring, 1983; Inger and Stuebing, 1992), although some morphological variations are recognized within the species (Dring, 1983). We examined intraspecific variations in this species from adult morphology, bioacoustics, and mtDNA sequences, and found that some populations form a clade that is heterospecific with the topotypic L. mjobergi. In this paper we describe the clade as a new species. 


\section{Materials ANd Methods}

For molecular analysis, total DNA was extracted from tissues preserved in $99 \%$ ethanol. Methods for DNA extraction, and following amplification and sequencing of mtDNA fragments (approximately 450 base pairs [bp] of 16S rRNA) are same as those reported by Matsui et al. (2010b). The resultant sequences were deposited in GenBank (Accession numbers LC056779-056794: Table 1). By using the obtained sequences and published data from GenBank (Table 1), we reconstructed mitochondrial genealogies based on the maximum likelihood (ML) method and Bayesian inference (BI).

For specimens stored in $70 \%$ ethanol, we took the following 21 body measurements following Matsui (1984): (1) snout-vent length (SVL); (2) head length (HL); (3) snout length (SL); (4) snout-nostril length (S-NL); (5) nostril-eyelid length (N-EL); (6) eye length (EL, including eyelid); (7) tympanum-eye length (T-EL); (8) tympanum diameter (TD); (9) head width (HW); (10) internarial distance (IND); (11) interorbital distance (IOD); (12) upper eyelid width (UEW); (13) lower arm and hand length (LAL) from elbow to tip of third finger; (14) hand length (HAL); (15) inner palmer tubercle length (IMPL); (16) third finger length (3FL); (17) hindlimb length (HLL); (18) tibia length (TL); (19) foot length (FL); (20) inner metatarsal tubercle length (IMTL); and (21) first toe length (1TOEL),

TABLE 1. Samples used for DNA analysis in this study, and GenBank accession numbers. BORN: BORNEENSIS collection, University Malaysia Sabah; KUHE: Kyoto University, Human and Environmental Studies; NMBE: Naturhistorisches Museum der Burgergemeinde Bern; SRC: Sarawak Research Collections, Forest Research Center Sarawak; SP: Sabah Parks; UNIMAS: Universiti Malaysia Sarawak; ZMH: Zoological Museum of Hamburg.

\begin{tabular}{|c|c|c|c|}
\hline Species & Locality & Voucher & Accession No. \\
\hline Leptobrachella sp. & Mulu NP, Sarawak, Borneo, Malaysia & SRC 00230/KUHE 49815 & LC056779 \\
\hline Leptobrachella sp. & Mulu NP, Sarawak, Borneo, Malaysia & KUHE 55333 & LC056780 \\
\hline Leptobrachella sp. & Mulu NP, Sarawak, Borneo, Malaysia & KUHE 55337 & LC056781 \\
\hline Leptobrachella sp. & Mulu NP, Sarawak, Borneo, Malaysia & KUHE 55340 & LC056782 \\
\hline Leptobrachella sp. & Lanjak Entimau, Sarawak, Borneo, Malaysia & KUHE 17554 & LC056783 \\
\hline Leptobrachella sp. & Lanjak Entimau, Sarawak, Borneo, Malaysia & KUHE 17557 & LC056784 \\
\hline L. "mjobergi" & Mulu NP, Sarawak, Borneo, Malaysia & ZMH A13129 & KJ831306 \\
\hline L. "mjobergi" & Mulu NP, Sarawak, Borneo, Malaysia & UNIMAS 8889 & KJ831307 \\
\hline L. "mjobergi" & Mulu NP, Sarawak, Borneo, Malaysia & NMBE 1056347 & KJ831308 \\
\hline L. mjobergi & Gading NP, Sarawak, Borneo, Malaysia & KUHE 17064 & LC056785 \\
\hline L. mjobergi & Gading NP, Sarawak, Borneo, Malaysia & KUHE 17207 & LC056786 \\
\hline L. mjobergi & Gading NP, Sarawak, Borneo, Malaysia & KUHE 47872 & LC056787 \\
\hline L. mjobergi & Gading NP, Sarawak, Borneo, Malaysia & KUHE 47876 & LC056788 \\
\hline L. mjobergi & Gading NP, Sarawak, Borneo, Malaysia & KUHE 48879 & LC056789 \\
\hline L. parva & Mulu NP, Sarawak, Borneo, Malaysia & KUHE 55307 & LC056790 \\
\hline L. parva & Mulu NP, Sarawak, Borneo, Malaysia & KUHE 55308 & LC056791 \\
\hline L. parva & Mulu NP, Sarawak, Borneo, Malaysia & UNIMAS 8883 & KJ831304 \\
\hline L. parva & Mulu NP, Sarawak, Borneo, Malaysia & UNIMAS 8623 & KJ831305 \\
\hline L. brevicrus & Mulu NP, Sarawak, Borneo, Malaysia & ZMH A09365 & KJ831302 \\
\hline L. brevicrus & Mulu NP, Sarawak, Borneo, Malaysia & UNIMAS 8957 & KJ831303 \\
\hline L. baluensis & Tambunan, Sabah, Borneo, Malaysia & SP 21604 & LC056792 \\
\hline L. baluensis & Kampong Lokos, Sabah, Borneo, Malaysia & SP 21687 & LC056793 \\
\hline L. baluensis & Crocker Range NP, Sabah, Borneo, Malaysia & BORN 08595 & LC056794 \\
\hline L. baluensis & Crocker Range NP, Sabah, Borneo, Malaysia & ZMH A13128 & KJ831301 \\
\hline Leptolalax gracilis & Mulu NP, Sarawak, Borneo, Malaysia & KUHE 55624 & AB847560 \\
\hline Leptobrachium hasseltii & Yogyakarta, Java, Indonesia & KUHE 42820 & AB530424 \\
\hline
\end{tabular}




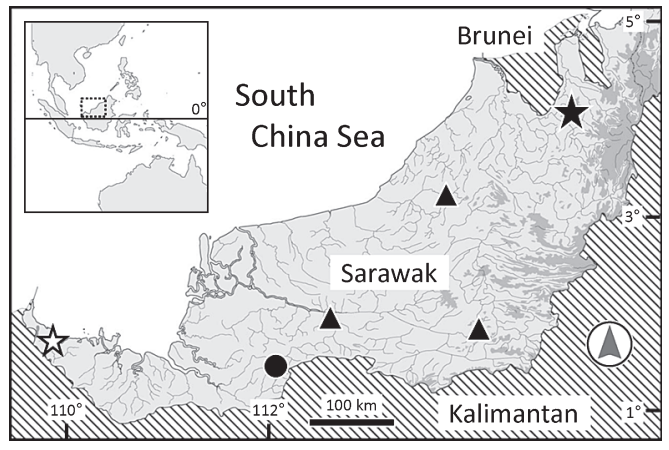

FIG. 1. Map of Sarawak, Malaysian Borneo, showing the type locality (filled star), the known distribution (filled circles), and the literature record (filled triangles) of Leptobrachella juliandringi sp. nov., with the type locality of $L$. mjobergi (open star).

from distal end of inner metatarsal tubercle to tip of first toe. We made all measurements with dial calipers to the nearest $0.05 \mathrm{~mm}$ under a binocular dissecting microscope.

In the morphometric analyses, Leptobrachella sp. from two localities of Sarawak (Mulu and Lanjak: Fig. 1) recognized by genetic analysis, and topotypic L. mjobergi from Gading, western Sarawak, were compared. In the univariate comparisons, SVL was compared by Student's $t$-test, while the remaining characters were converted to ratios to SVL (R) and compared by the Mann-Whitney U test.

We recorded frog calls in the field using digital recorders (Olympus LS-11, V-85, and V-823) at $44.1 \mathrm{kHz} / 16$ bits as uncompressed wave files, and analyzed recordings with Raven Lite 1.0 for Windows (http://www.birds.cornell.edu/raven). Both temporal and frequency information were obtained from the audiospectrograms.

\section{Systematics}

We obtained $458 \mathrm{bp}$ of concatenated fragments of mitochondrial 16S rRNA gene (Fig. 2), within which 103 were variable and 95 were parsimoniously informative. The best substitution model was $\mathbf{J} 2$ (Jobb, 2011) with gamma shape parameter $(\Gamma)$ for $\mathrm{ML}$ and GeneralTime-Reversible (GTR) $+\Gamma$ for BI, respectively. The likelihood values (-lnLs) of the
ML tree and the summarized BI trees were 3273.866 and 3316.464, respectively. Phylogenetic relationships obtained from both analyses were nearly identical, and only the ML tree is shown in Fig. 2. The species of Leptobrachella analyzed formed a monophyletic group against outgroups $(\mathrm{BS}=97 \% / \mathrm{BPP}=1.00)$. Each species was also shown to be monophyletic, but three sequences labeled as L. mjobergi from Gunung (Gn.=Mt.) Mulu in GenBank were separated from the topotypes of this species and embedded in our Leptobrachella sp. from Sarawak. Overall, samples analyzed tended to be split into two groups: One group with poor statistical support $(\mathrm{BS}=61 \% / \mathrm{BPP}=0.62)$ consisted of Leptobrachella sp. and topotypic $L$. mjobergi; and another group forming a clade $(\mathrm{BS}=91 \% / \mathrm{BPP}=0.99)$ contained $L$. parva, L. brevicrus, and L. baluensis, within which the former two were phylogenetically close. The genetic divergence (uncorrected p-distance) between Leptobrachella sp. from Sarawak and L. mjobergi was large, with a mean of $12.7 \%$ (range=12.2-13.8: Table 2). This value was comparable to, and even larger than, those found among other named species (e.g., 6.6 to $6.9 \%$ between $L$. parva and $L$. brevicrus: Table 2).

In addition to clear genetic separation, the specimens of Leptobrachella sp. from Sarawak were also clearly distinguished morphologically and acoustically from other congeners. We thus describe it as follows:

Leptobrachella juliandringi sp. nov. <English name: Dring's Dwarf Litter Frog > Figs. 3, 4

Nesobia mjobergi: Inger, 1966: 49 (part).

Leptobrachella mjobergi: Dring, 1983: 92 (part); Inger, 1983: 27 (part); Inger, 1985: 6 (part); Oberhummer et al., 2014: 63.

\section{Etymology}

The species is named in honor of Mr. Julian Dring in recognition of his great contribution to the taxonomic study of the Bornean amphibians. 


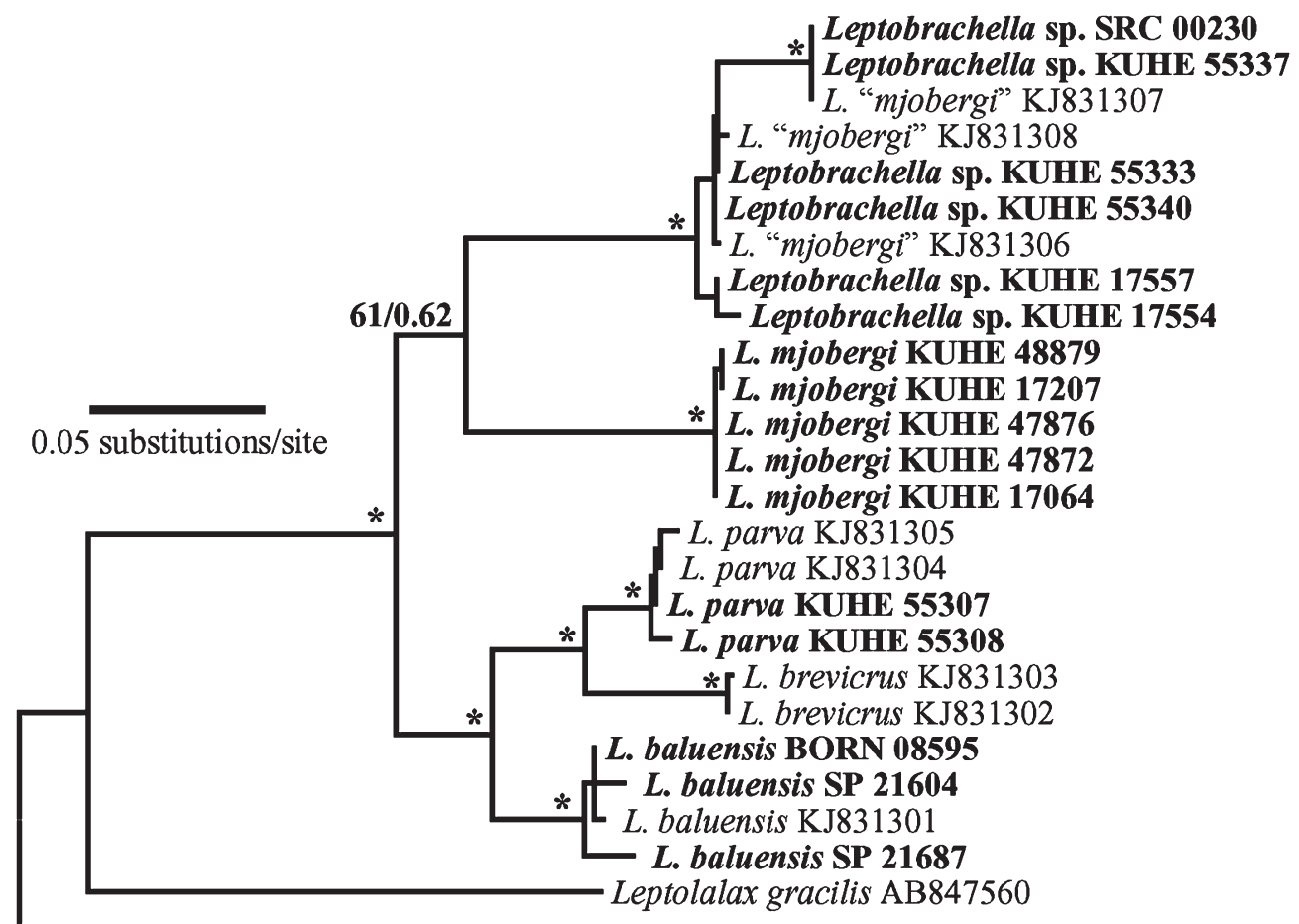

Leptobrachium hasseltii AB847561

FIG. 2. Maximum likelihood (ML) tree of a 458 bp sequence of mitochondrial 16S rRNA for samples of Leptobrachella (for sample details, see Table 1). Asterisks indicate the nodes with statistical support ( $B S \geq 70 \%$ and $B P P \geq 0.95$ ). Numbers above nodes represent the support values (BS/BPP). Newly obtained sequences are shown in bold type.

TABLE 2. Mean and range (in parenthesis) of uncorrected p-distance (\%) for fragments of 16S rRNA compared among Leptobrachella taxa.

\begin{tabular}{ccccccc}
\hline & & 1 & 2 & 3 & 4 & 5 \\
\hline 1 & Leptobrachella sp. & 0.6 & & & & \\
& & $(0.0-2.2)$ & & & & \\
2 & L. mjobergi & 12.7 & 0.2 & & & \\
& & $(12.2-13.8)$ & $(0.0-0.3)$ & & & \\
3 & L. brevicrus & 12.9 & 14.3 & 0.3 & & \\
& & $(12.7-13.8)$ & $(14.1-14.6)$ & - & & \\
4 & L. parva & 13.6 & 12.5 & 6.8 & 0.2 & \\
& & $(13.3-14.1)$ & $(12.4-12.7)$ & $(6.6-6.9)$ & $(0.0-0.3)$ & 1.7 \\
5 & L. baluensis & 13.0 & 11.8 & 10.9 & 7.0 & $(0.3-3.0)$ \\
\hline
\end{tabular}

\section{Holotype}

Sarawak Research Collections (SRC) 00230 (former Graduate School of Human and Environmental Studies, Kyoto University [KUHE] 48915), an adult male from Camp 2 of Gn. Mulu National Park, Sarawak, Malaysia $\left(04^{\circ} 02^{\prime} 20^{\prime \prime} \mathrm{N}, 114^{\circ} 52^{\prime} 20^{\prime \prime} \mathrm{E}, 530 \mathrm{~m}\right.$ asl), collected on 2 March 2014 by K. Eto and K. Nishikawa. 


\section{Paratypes}

All from Sarawak. KUHE 48916-48919, four males, data same as the holotype; SRC unnumbered (former KUHE 55334, one male) and KUHE 55333 (one female), 55337-55341 (five males), collected on 4 March 2013 by K. Eto and K. Nishikawa from the type locality; KUHE 10463, one male, collected on 23 December 1989 by M. Matsui from the type locality.

\section{Referred specimens}

KUHE 10590, 10618-10627, 10671-80 (21 males), and 10628 (one female) collected between 10 and 15 January 1990 by M. Matsui, KUHE 10697, one male, collected on 19 January 1990 by D. Labang from Sungai Beloh, a tributary of Sungai (=River) Katibas, Bukit Lanjak, Division Sri Aman, Sarawak; KUHE 17557, one male, from Sungai Jerak, a branch of Sungai Engkari, Bukit Lanjak, Division Sri Aman, Sarawak $\left(01^{\circ} 20^{\prime} \mathrm{N}\right.$, $112^{\circ} 00^{\prime} \mathrm{E}, 250 \mathrm{~m}$ asl), collected on 31 August 1993 by M. Matsui.

\section{Diagnosis}

A large form of the genus (males 17.4$19.1 \mathrm{~mm}$, females $18.8-19.1 \mathrm{~mm}$ in SVL); reddish- or pale-brown dorsally with dark brown marking, inverted triangle shape on head, W-shape on shoulder, and inverted V-shape on sacral region; tibiotarsal articulation of adpressed limb reaching or beyond nostril; tip of digit sharply pointed, forming arrow-like projection. The new species is superficially similar to L. mjobergi, but can be distinguished from it and all the other congeners by the combination of the following characteristics: a series of elongate ventrolateral glands present; black marking on side of body absent; ventrum light-colored and unpigmented posteriorly, but darkly pigmented with white spots ("broken brown network" of Dring, 1983) on anterior part and sides; male with pale, strap-like lineae masculinae; poorly developed toe webs; chirpy-call with 7.0 to $8.9 \mathrm{kHz}$ in dominant frequency.

\section{Description of holotype (measurements in $\mathrm{mm}$ )}

SVL 19.1; habitus moderately slender (Fig. $3 \mathrm{~A}-\mathrm{C}$ ); head longer (HL 7.3, 38.2\% SVL) than broad (HW 6.9, 36.1\% SVL); snout rounded, projecting beyond lower jaw; eye large, length (EL 2.9, 15.2\%SVL) slightly greater than snout length (SL 2.6, 13.6\% SVL); canthus distinct, slightly constricted; lore slightly oblique, concave; nostril lateral, below canthus, about midway between tip of snout and eye; internarial distance (IND 2.3, 11.9\% SVL) larger than interorbital distance (IOD 2.0, $10.5 \%$ SVL) and upper eyelid (UEW 1.9, $10.0 \%$ SVL); pupil diamond shaped; pineal spot absent; tympanum distinct, diameter (TD 1.2, 6.3\% SVL) two-fifths that of eye, and separated from eye by half of tympanum diameter (T-EL 0.6, 3.1\% SVL); vomerine teeth absent; tongue weakly notched posteriorly, without papillae; subgular vocal sac bipartite, consisting of two ventrolaterally situated parts, with a small opening near each jaw commissure.

Forelimb slender (LAL 8.2, 42.9\% SVL); fingers slender, unwebbed; finger length formula: $\mathrm{I}<\mathrm{II}<\mathrm{IV}<$ III (Fig. 4A); finger tips sharply pointed, forming arrow-like projections; no fringes of skin along fingers; inner palmar tubercle large (IPTL 1.5, 7.9\% SVL); subarticular tubercles indistinct, replaced by indistinct, low callous tissue; nuptial pads absent. Hindlimb moderately long (HLL 32.7, $171.2 \%$ SVL); tibia moderately long (TL 10.3, $53.9 \%$ SVL), heels overlapping when limbs are held at right angles to body; tibiotarsal articulation of adpressed limb reaching to point between nostril and snout tip; foot (FL 9.3, $48.7 \%$ SVL) shorter than tibia; toe length formula $\mathrm{I}<\mathrm{II}<\mathrm{V}<\mathrm{III}<\mathrm{IV}$; toe tips similar to those of fingers; webbing confined to bases of toes (Fig. 4B), formula: I 13/4-2 $2^{+}$II $13 / 4-3^{+}$III $22 / 3-34 / 5$ IV $3 \frac{4}{5}-23 / 4$ V; toes with lateral fringes; subarticular tubercles obscure, but elongate, replaced by low callous tissue; inner metatarsal tubercle low, length (IMTL 1.4, 7.3\% SVL) slightly longer than first toe (1TOEL 1.2, 6.3\% SVL); no outer metatarsal tubercle.

Skin dorsally nearly smooth with few small 


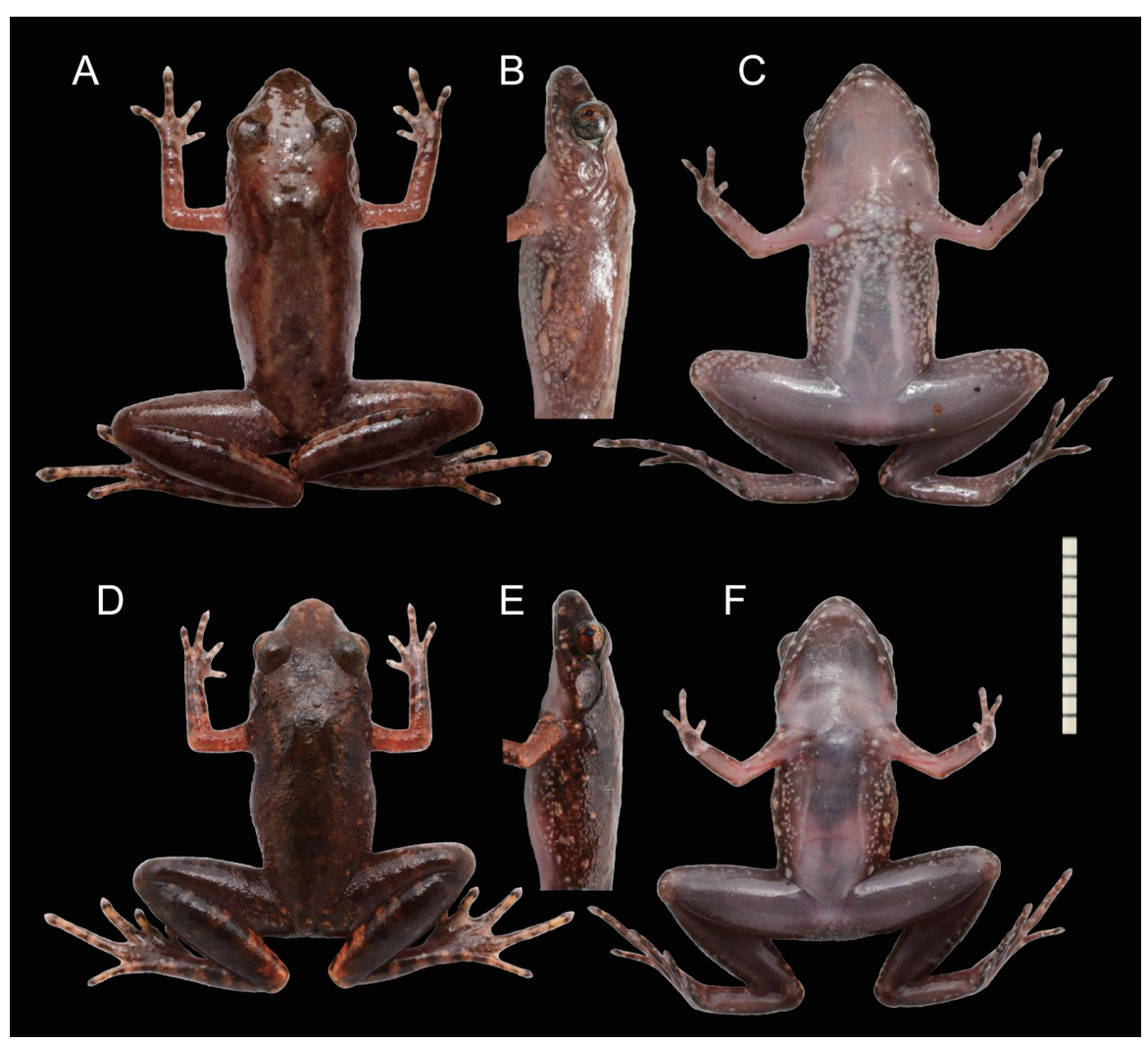

FIG. 3. Dorsal (A, D), lateral (B, E), and ventral (C, F) views of male holotype of Leptobrachella juliandringi sp. nov. (A-C, SRC00230 [former KUHE 48915]) and a topotypic male of L. mjobergi (D-F: KUHE 47872). Scale bar $=10 \mathrm{~mm}$.

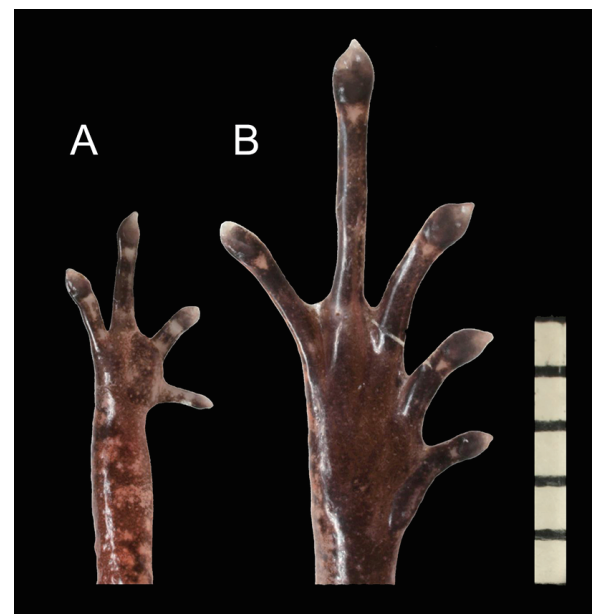

FIG. 4. Ventral view of right hand (A) and foot (B) of male holotype of Leptobrachella juliandringi sp. nov. (SRC 00230). Scale bar $=5 \mathrm{~mm}$. tubercles (Fig. 3A); a low supratympanic ridge from eye to axilla; a relatively large tubercle on just behind of jaw commissure; side of body weakly granular with scattered tubercles/glands (Fig. 3B); chest and abdomen smooth (Fig. 3C); pectoral gland distinct but flat; supraaxillary gland small; ventrolateral glands elongate, forming a row; femoral gland indistinct, in small pale spot.

\section{Color}

In life, reddish-brown dorsally on head and body with dark markings: inverse triangle shape on upper eyelid and interorbital space, $\mathrm{W}$-shape on shoulder, and inverse V-shape on sacral region; groin with dark marking restricted to cloacal region; side of head brownish like the dorsum; dark band below 
canthus rostralis; no dark tympanic mask; a light brown stripe from between nostrils to anteriormost edge of upper jaw; upper lip barred with dark and light brown; flank brownish slightly paler than dorsum; pectoral and supraaxillary glands white and pinkish brown, respectively; elongate pinkish glands on ventrolateral region; light-colored ventrally on head, body, and limbs; throat unpigmented except for dark brown mottling on edge of lower jaw; anterior and lateral parts of belly dark brown, pigmented with many white spots; posterior part of belly largely unpigmented; pinkish strap-like lineae masculinae visible through ventral skin; forelimb light brown dorsally with dark crossbars on lower arm and fingers, nearly unpigmented ventrally; hindlimb brown dorsally with indistinct light and dark crossbars, ventrally dark brown, pigmented with white except for base of thigh; underside of hand and foot blackish; iris orange in upper part and along outer margin of pupil, gold with black reticulation in lower part.

In preservative, color and pattern generally faded but not obviously changed except for iris; supraaxillary and ventrolateral glands becoming white; lineae masculinae becoming grayish.

\section{Variation}

Individuals of the type series are generally similar to each other in morphology. Variation in size and body proportions is shown in Table 3 together with those of the allied species, $L$. mjobergi. Males from two different localities (Mulu and Lanjak) do not differ significantly in size and proportions of body parts $(\mathrm{P}>0.05)$. Females show relatively larger SVL than males. Tibiotarsal articulation of adpressed limb reaches nostril, tip of snout, or beyond snout in males, but nostril or tip of snout in females. Dorsal coloration varies among individuals, from reddish- to pale-brown. Dorsal markings are indistinct in some individuals. Ventrolateral glands usually distinctly elongated, but sometimes nearly round or poorly developed. The number of femoral glands usually varies from
TABLE 3. Measurements in adults of Leptobrachella juliandringi sp. nov. and L. mjobergi. Mean SVL (in $\mathrm{mm}$ ) and medians of ratios (R) of other characters to SVL, followed by ranges in parenthesis. See text for character abbreviations. Values in bold type indicate measurements with significant difference between males of the two species.

\begin{tabular}{|c|c|c|c|}
\hline & \multirow{2}{*}{$\begin{array}{c}\text { L. mjobergi } \\
14 \mathrm{M}\end{array}$} & \multicolumn{2}{|c|}{ L. juliandringi sp. nov. } \\
\hline & & $15 \mathrm{M}$ & $2 \mathrm{~F}$ \\
\hline SVL & $\begin{array}{c}16.8 \\
(15.7-19.0)\end{array}$ & $\begin{array}{c}17.9 \\
(17.0-19.2)\end{array}$ & $\begin{array}{c}18.9 \\
(18.8-19.1)\end{array}$ \\
\hline RHL & $\begin{array}{c}38.2 \\
(35.3-41.8)\end{array}$ & $\begin{array}{c}38.3 \\
(34.5-39.3)\end{array}$ & $\begin{array}{c}38.1 \\
(37.8-38.3)\end{array}$ \\
\hline RSL & $\begin{array}{c}12.6 \\
(11.6-13.5)\end{array}$ & $\begin{array}{c}13.6 \\
(12.3-14.2)\end{array}$ & $\begin{array}{c}12.3 \\
(12.2-12.3)\end{array}$ \\
\hline RS-NL & $\begin{array}{c}6.8 \\
(6.2-7.3)\end{array}$ & $\begin{array}{c}6.9 \\
(6.1-7.2)\end{array}$ & $\begin{array}{c}6.1 \\
(5.9-6.3)\end{array}$ \\
\hline RE-NL & $\begin{array}{c}5.8 \\
(5.3-6.5)\end{array}$ & $\begin{array}{c}6.3 \\
(6.2-6.9)\end{array}$ & $\begin{array}{c}6.4 \\
(6.4-6.5)\end{array}$ \\
\hline REL & $\begin{array}{c}16.5 \\
(14.7-17.9)\end{array}$ & $\begin{array}{c}15.9 \\
(15.3-16.5)\end{array}$ & $\begin{array}{c}16.2 \\
(16.0-16.5)\end{array}$ \\
\hline RT-EL & $\begin{array}{c}3.2 \\
(2.1-3.9)\end{array}$ & $\begin{array}{c}2.9 \\
(2.7-4.0)\end{array}$ & $\begin{array}{c}2.5 \\
(1.6-3.4)\end{array}$ \\
\hline RTD & $\begin{array}{c}6.0 \\
(4.2-7.5)\end{array}$ & $\begin{array}{c}5.7 \\
(4.8-6.5)\end{array}$ & $\begin{array}{c}5.5 \\
(4.8-6.2)\end{array}$ \\
\hline RHW & $\begin{array}{c}36.8 \\
(33.7-39.0)\end{array}$ & $\begin{array}{c}36.5 \\
(34.3-37.9)\end{array}$ & $\begin{array}{c}37.1 \\
(36.7-37.6)\end{array}$ \\
\hline RIND & $\begin{array}{c}12.4 \\
(10.0-13.4)\end{array}$ & $\begin{array}{c}12.1 \\
(11.2-12.4)\end{array}$ & $\begin{array}{c}11.3 \\
(10.9-11.7)\end{array}$ \\
\hline RIOD & $\begin{array}{c}9.5 \\
(8.6-12.1)\end{array}$ & $\begin{array}{c}10.0 \\
(8.6-10.5)\end{array}$ & $\begin{array}{c}8.8 \\
(8.8-8.8)\end{array}$ \\
\hline RUEW & $\begin{array}{c}9.4 \\
(8.2-10.7)\end{array}$ & $\begin{array}{c}9.8 \\
(8.5-10.4)\end{array}$ & $\begin{array}{c}9.7 \\
(9.6-9.9)\end{array}$ \\
\hline RLAL & $\begin{array}{c}41.8 \\
(39.1-44.1)\end{array}$ & $\begin{array}{c}42.4 \\
(40.3-44.8)\end{array}$ & $\begin{array}{c}42.8 \\
(44.4-41.2)\end{array}$ \\
\hline RHAL & $\begin{array}{c}20.8 \\
(19.1-22.0)\end{array}$ & $\begin{array}{c}21.1 \\
(19.3-23.5)\end{array}$ & $\begin{array}{c}22.1 \\
(22.1-22.2)\end{array}$ \\
\hline RIPTL & $\begin{array}{c}8.9 \\
(7.0-11.9)\end{array}$ & $\begin{array}{c}7.8 \\
(7.5-9.2)\end{array}$ & $\begin{array}{c}8.4 \\
(8.5-8.3)\end{array}$ \\
\hline R3FL & $\begin{array}{c}12.0 \\
(10.6-15.6)\end{array}$ & $\begin{array}{c}12.6 \\
(11.2-13.6)\end{array}$ & $\begin{array}{c}12.6 \\
(12.5-12.7)\end{array}$ \\
\hline RHLL & $\begin{array}{c}169.1 \\
(146.3-175.1)\end{array}$ & $\begin{array}{c}174.6 \\
(156.1-187.6)\end{array}$ & $\begin{array}{c}175.5 \\
(168.4-182.7)\end{array}$ \\
\hline RTL & $\begin{array}{c}55.3 \\
(50.0-58.1)\end{array}$ & $\begin{array}{c}56.9 \\
(50.1-59.9)\end{array}$ & $\begin{array}{c}57.0 \\
(55.2-58.8)\end{array}$ \\
\hline RFL & $\begin{array}{c}46.4 \\
(44.7-49.4)\end{array}$ & $\begin{array}{c}47.3 \\
(46.1-49.2)\end{array}$ & $\begin{array}{c}48.1 \\
(47.8-48.4)\end{array}$ \\
\hline RIMTL & $\begin{array}{c}7.7 \\
(6.2-9.4)\end{array}$ & $\begin{array}{c}7.5 \\
(6.6-9.2)\end{array}$ & $\begin{array}{c}6.7 \\
(6.2-7.2)\end{array}$ \\
\hline R1TOEL & $\begin{array}{c}6.9 \\
(4.1-8.3)\end{array}$ & $\begin{array}{c}7.5 \\
(6.2-8.7)\end{array}$ & $\begin{array}{c}8.6 \\
(8.2-9.0)\end{array}$ \\
\hline
\end{tabular}


one to five, but the glands are indistinct and hardly recognizable in some individuals.

\section{Call characteristics}

The advertisement calls of the holotype (KUHE 48915: Fig. 5) and topotypic individuals, recorded at the Camp 2 of Mulu National Park at air temperatures of $21.8-23.5 \mathrm{C}$, showed similar temporal and frequency characteristics. These calls consisted of a long series of short, chirpy notes, and the call length $(1.2-2.0 \mathrm{~min}, \mathrm{n}=3)$ and the number of notes within a series $(47-113, n=3)$ were variable. Note repetition rate was $0.88 \pm 0.36$ (mean $\pm \mathrm{SD} ; 0.63-1.55, \mathrm{n}=5$ ) per s. Individual notes lasted 60.4 $\pm 14.7(41.0-85.5, \mathrm{n}=20) \mathrm{ms}$ and were separated from each other by an interval of ca. $0.5 \mathrm{~s}$ in the middle of a call and ca. $1.2 \mathrm{~s}$ in the beginning (overall: $0.94 \pm 0.37$, $0.42-1.45, \mathrm{n}=20$ ). Each note was composed of $14.3 \pm 2.4(12-18, \mathrm{n}=15)$ pulses, within which the first one or two were usually separated from the subsequent pulses. The dominant frequency was $7.68 \pm 0.49(7.00-8.20, n=20)$
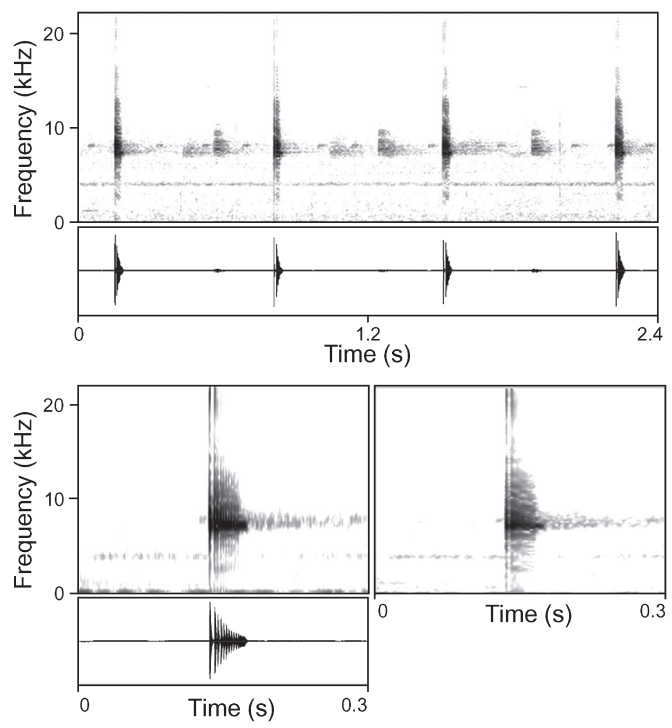

FIG. 5. Sonagram and wave form (128 point window for top and bottom left, and 256 point window for bottom right) showing advertisement calls of the holotype of Leptobrachella juliandringi sp. nov. (SRC 00230) recorded at an air temperature of $21.8 \mathrm{C}$.
$\mathrm{kHz}$. A harmonic frequency was detected at ca. $20-22 \mathrm{kHz}$ in the call of the holotype, probably because of the quieter environment in which the recording was made. Frequency modulation was usually indistinct, but slight modulation was observed in some calls (Fig. 5). These characteristics seemed to be essentially identical with those previously described for L. mjobergi from Mulu Camp 2 (note length $60-70 \mathrm{~ms}$ and dominant frequency $7.2-8.0 \mathrm{kHz}$ at $22 \mathrm{C}$ ) by Dring (1983).

\section{Comparisons}

Leptobrachella juliandringi $\mathrm{sp}$. nov. is separated from the other congeneric species by the presence of a series of elongate ventrolateral glands, except for some topotypic specimens (ca. 10\%; Eto, unpublished data) of L. mjobergi and L. baluensis from Gn. Mulu (Dring, 1983) that also have similar glands. By the presence of ventrum marking (dark pigmentation with white spots) on the anterior and lateral parts of the belly, the new species is also distinguishable from the other congeners as follows (all in alcohol): belly of $L$. mjobergi largely unpigmented with such ventral marking only on the lateral part (present study); $L$. baluensis have similar marking (pale or dark pigmentation with small light spots) usually on entire belly (Dring, 1983; present study); belly largely unpigmented or pigmented palely in L. parva, with dense white spots on the lateral part (Dring, 1983; present study); belly white in L. palmata (Inger and Stuebing, 1992); belly faded and without evident pattern in L. natunae and L. serasanae (Dring, 1983). Leptobrachella brevicrus should also have similar ventral marking ("belly with many small unpigmented spots": Dring, 1983) but we could not examine any specimens. Males of the new species have broad, strap-like lineae masculinae that are thin and thread like (L. mjobergi and L. parva: present study; Dring, 1983), present but indistinct (L. palmate: Inger and Stuebing, 1992), or not evident even on dissection (L. baluensis and $L$. brevicrus: Dring, 1983) in the other species. From L. baluensis, L. natunae, and $L$. 
serasanae, L. juliandringi $\mathrm{sp}$. nov. is differentiated by the absence of large black markings on the flanks. From L. palmata, the new species is differentiated by the poorly developed toe webs (toe webs well-developed in $L$. palmata). The new species has a longer tibia relative to SVL (RTL=53.9-58.8: Table 3) than L. brevicrus (RTL=43.6-46.1: Dring, 1983). In body size, the new species (males $17.4-19.1 \mathrm{~mm}$, female $19.1 \mathrm{~mm}$ in SVL) is much larger than L. palmata (males 14.4$16.8 \mathrm{~mm}$ : Inger and Stuebing, 1992), L. parva (males 15.0-16.9 mm; female $17.8 \mathrm{~mm}$ : Dring, 1983), and $L$. serasanae (female $16.9 \mathrm{~mm}$ : Dring, 1983). In males, L. juliandringi sp. nov. show significantly larger SVL as well as a longer snout, arm and hand, hind limb, tibia, foot, and first toe, all relative to SVL $(\mathrm{P}<0.05$ : Table 3), than topotypic L. mjobergi.

The new species also has a unique, chirpy call, which is distinct from the advertisement calls of $L$. mjobergi, L. brevicrus, and $L$. parva, which are composed of buzzes (Dring, 1983; Matsui, unpublished data). Topotypic
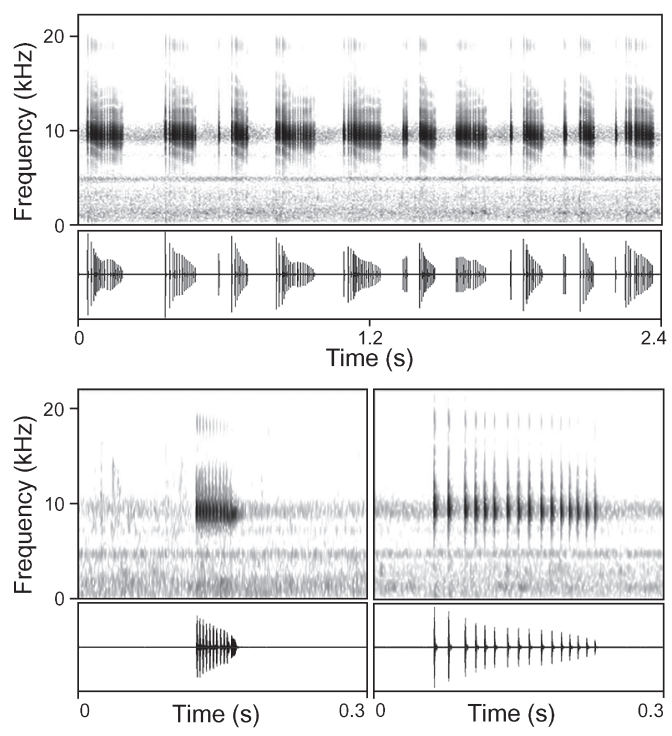

FIG. 6. Sonagram and wave form (128 point window) showing advertisement calls of topotypic male of L. mjobergi (KUHE 47872) recorded at an air temperature of $25.3 \mathrm{C}$. Bottom left and right are notes in the beginning and the middle of the call, respectively.
L. mjobergi has a distinct buzzy call, which is different from the call of $L$. juliandringi $\mathrm{sp}$. nov. in the following way (Fig. 6): the calls consist of a long series of notes with a variable call length ranging from 0.2 to $1.5 \mathrm{~min}$ and a series of note numbers ranging from 45 to 270 $(\mathrm{n}=8$; vs. $47-113$ in L. juliandringi); note repetition rate of 3.29 (mean; $2.98-3.45, \mathrm{n}=8$; vs. $0.88[0.63-1.55])$ per $s$; variable note length, $43.4(38.7-50.2, \mathrm{n}=10) \mathrm{ms}$ in the beginning or when inactive, to 170.4 (131.2-209.8, $\mathrm{n}=22) \mathrm{ms}$ in the middle ( $\mathrm{n}=8$; vs. 60.4 [41.0 $85.5]$ ); also variable note interval, ca. $0.5 \mathrm{~s}$ in the beginning and ca. 0.1 in the middle $(n=8$; vs. ca. 1.2 and 0.5$) ; 15.7(12-18, \mathrm{n}=32)$ pulses per note, within which the first one to three pulses were sometimes separated from the subsequent ones (vs. 14.3 [12-18]); dominant frequency $9.50(9.32-9.60, \mathrm{n}=32) \mathrm{kHz}$ with slight modulation (vs. 7.68 [7.00-8.20]); a harmonic frequency is recognized at ca. 18.5$19.5 \mathrm{kHz}(\mathrm{n}=15)$ in some calls (vs. $20-22 \mathrm{kHz}$ ).

\section{Range}

Northeastern to Central Sarawak, eastern Malaysia. Beside the type locality (Camp 2 of $\mathrm{Gn}$. Mulu, $530 \mathrm{~m}$ asl), the species was obtained from Bukit Lanjak (ca. 240-340 $\mathrm{m}$ asl). Based on literature records (Dring, 1983: as Leptobrachella sp. 2 or L. mjobergi from Central Sarawak), it also occurs on Camp 1 of Gn. Mulu, Nanga Tekalit, Tubau, and Sungai Putai.

\section{Natural history}

In the type locality, males seemed to prefer calling from open places such as on leaves (ca. 0.2 to $0.8 \mathrm{~m}$ above the ground or the water surface: Fig. 7), close to small streams (ca. 1 to $3 \mathrm{~m}$ wide). Males were seldom found calling on the ground or in hidden places. These habitat selections are similar to those of topotypic L. mjobergi, males of which also preferred open places for calling, but were often found calling on the ground and the rocks (Matsui and Eto, unpublished data). The eggs, the tadpoles, and the oviposition site are unknown, although some previous studies on 


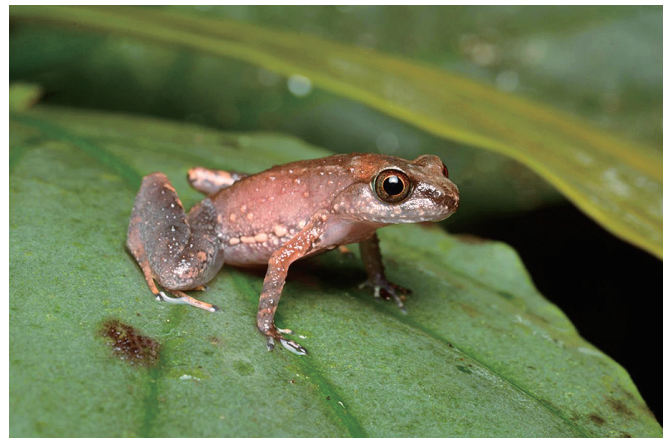

FIG. 7. Dorsolateral view of a male paratype of Leptobrachella juliandringi sp. nov. (SRC 00230) from the type locality.

the larvae of L. mjobergi (e.g., Inger, 1983, 1985) may contain information on the tadpoles of the new species.

\section{DisCUSSION}

Leptobrachella juliandringi sp. nov. has been confused with L. mjobergi for a long time. This species is surely allied to Leptobrachella sp. 2 in Dring (1983) from its morphological and bioacoustic traits, and the locality information. Dring (1983) admitted that his Leptobrachella sp. 2 might be heterospecific from true L. mjobergi, but he did not split them because of their morphological similarities. As he could examine only the holotype and a paratype of $L$. mjobergi (moreover, the latter had been damaged by the dissection: Dring, 1983) and could not gain access to other topotypic samples or acoustic data of $L$. mjobergi, he was not able to conclude that his Leptobrachella sp. 2 (or L. mjobergi from Central Sarawak in his article) was a good species. In this study, we examined a sufficient number of $L$. mjobergi topotypes and their calls, and ascertained that Leptobrachella sp. 2 sensu Dring is a distinct species, L. juliandringi. Possibly because Dring's (1983) study was more detailed than the original description by Smith (1925), many later authors (e.g., Inger and Stuebing, 1992; Malkmus et al., 2002) followed it and considered the traits of his Leptobrachella sp.2 (=L. juliandringi sp. nov.) as those of L. mjobergi. For example, in proposing an identification key of Bornean Leptobrachella, Inger and Stuebing (1992) treated elongate ventrolateral glands as a diagnostic character of L. mjobergi. However, such a trait is actually not typical in the topotypic population of $L$. mjobergi but is common in L. juliandringi as mentioned above. Although L. mjobergi is now thought to occur widely through Sarawak and a part of Kalimantan (Inger and Stuebing, 1997), some of these distributional records should be replaced by those of $L$. juliandringi. Reexamination of the inventory of this group is an urgent issue.

Dring (1983) split the genus Leptobrachella into two groups based on their call characteristics, i.e., a group of species with a buzzy call and another with a chirpy call. On the basis of this division and the similarity in the shape of the flank glands, he suggested a close relationship between Leptobrachella sp. 2 or $L$. mjobergi $(=L$. juliandringi sp. nov.) and $L$. baluensis, but the phylogenetic pattern obtained in our study does not support such a hypothesis (Fig. 2). Moreover, our tree suggests that neither of buzzy calling ( $L$. brevicrus, $L$. parva, and L. mjobergi) nor the chirpy calling species ( $L$. baluensis and $L$. juliandringi sp. nov.) form monophyletic groups. Because not all species of the genus were available and the genetic marker analyzed was limited, the present phylogenetic tree is merely tentative, and further studies are necessary in order to clarify the evolutionarily history of this genus.

In the Mulu N. P., the new species occurs parapatrically with lowland species (L. parva) and highland species (L. baluensis and $L$. brevicrus) on Mt. Mulu (Dring, 1983), and their distribution seems to be stratified by altitude. Inger and Stuebing (1992) also suggested such altitudinal stratification in this genus. This distributional pattern differs from other Bornean stream breeding species like Ansonia and Leptolalax, in which often two (or more) species occur sympatrically (Matsui et al., 2010a; Matsui et al., 2014a, b). As a 
mechanism which allows co-occurrence of congeneric species, Matsui et al. (2010a) hypothesized that the adult body size differentiation is related to the prevailing sympatric distribution of Ansonia species. In Leptobrachella, body sizes of each species are not drastically different but are restricted to small ranges (males ca. 14-17 $\mathrm{mm}$ in SVL in smaller species [L. baluensis, L. palmata, and L. parva] and ca. $17-20 \mathrm{~mm}$ in larger species [L. brevicrus, $L$. juliandringi sp. nov., and $L$. mjobergi]: Dring, 1983; Inger, 1966; Inger and Stuebing, 1992; present study), and this uniformity in body size (or ecological and/or evolutionary factors, which might restrict their body size) might have affected their distributional pattern. However, detailed information on distribution, body size variations, and ecological characteristics of each species is lacking at present. Thus, the reason for non-sympatric occurrence of Leptobrachella spp. remains undetermined at present, and further survey in a wider area of Borneo and adjacent islands is necessary.

\section{ACKNOWLEDGEMENTS}

The Economic-Planning Unit (former SocioEconomic Research Unit) of Malaysia, the State Government of Sarawak, and Sabah Parks kindly permitted us to conduct the project, and Universiti Malaysia Sabah, JICA, the Sarawak Forestry Corporation, and the Sarawak Biodiversity Centre kindly provided all the facilities for conducting research. We are grateful to Datu Haji Len Talif Salleh, Haji Ali Bin Yusop, Marker Nyogin, Mohd. Shabudin Sabki, Uning, Haji Abang Mohamad Mohtar Bin Abang Pawozan, Paulus Ak Meleng, Mohamad Yazid Hossman, Fatimah Binti Mohammad, Brian Clark, and T. Ichioka for their encouragement and/or permission to conduct research and export specimens, to L. Apin, the late A. A. Hamid, T. Hikida, T. Kusano, D. Labang, M. B. Lakim, M. Maryati, T. Shimada, A. Sudin, T. Tachi, and P. Yambun for their field companionship, and to A. Hamidy for laboratory assistance. We thank two anonymous reviewers for providing helpful comments that improved the early version of the manuscript. Field trips were made possible by grants from The Monbusho International Scientific Research Program (Field Research, 01041051, 02041051, 04041068, 06041066, and 08041144) and The Monbukagakusho through the Japanese Society for the Promotion of Sciences (JSPS: Field Research, 15370038, 20405013, and 23405014) to MM and by the Shikata Memorial Trust for Nature Conservation to KE.

\section{Literature Cited}

Dehling, J. M. and Matsui, M. 2013. A new species of Leptolalax (Anura: Megophryidae) from Gunung Mulu National Park, Sarawak, East Malaysia (Borneo). Zootaxa 3670: 33-44.

DrING, J. 1983. Frogs of the genus Leptobrachella (Pelobatidae). Amphibia-Reptilia 4: 89-102.

INGER, R. F. 1966. The systematics and zoogeography of the Amphibia of Borneo. Fieldiana: Zoology 52: 1-402.

INGER, R. F. 1983. Larvae of southeast Asian species of Leptobrachium and Leptobrachella (Anura: Pelobatidae). pp. 13-32. In: A. Rhodin and K. Miyata (Eds.), Advances in Herpetology and Evolutionary Biology. Museum of Comparative Zoology, Cambridge.

INGER, R. F. 1985. Tadpoles of the forested regions of Borneo. Fieldiana: Zoology 26: 1-89.

Inger, R. F. And Stuebing, R. B. 1992 (1991). A new species of frog of the genus Leptobrachella Smith (Anura: Pelobatidae), with a key to the species from Borneo. Raffles Bulletin of Zoology 39: 99-103.

Inger, R. F. And Stuebing, R. B. 1997. A Field Guide to the Frogs of Borneo. Natural History Publications Sdn. Bhd., Kota Kinabalu.

Joвв, G. 2011. TREEFINDER version of March 2011. Distributed by the author via http://www. treefnder.de.

Malkmus, R., Manthey, U., Vogel, G., Hoffman, P., AND Kosuch, J. 2002. Amphibians and Reptiles of Mount Kinabalu (North Borneo). ARG Gantner Verlag Kommanditgesellschaft, Ruggell. 
Matsui, M. 1984. Morphometric variation analyses and revision of the Japanese toads (Genus Bufo, Bufonidae). Contributions from the Biological Laboratory, Kyoto University 26: 209-428.

Matsui, M., Tominaga, A., Liu, W.-Z., Khonsue, W., Grismer, L. L., Diesmos, A. C., DAs, I., Sudin, A., Yambun, P., Yong, H.-S., Sukumaran, J., AND Brown, R. M. 2010a. Phylogenetic relationships of Ansonia from Southeast Asia inferred from mitochondrial DNA sequences: Systematic and biogeographic implications (Anura: Bufonidae). Molecular Phylogenetics and Evolution 54: 561-570.

Matsui, M., Hamidy, A., Murphy, R. M., Khonsue, W., Yambun, P., Shimada, T., Norhayati, A., Daicus, M. B., And Jiang, J. P. 2010 b. Phylogenetic relationships of megophryid frogs of the genus Leptobrachium (Amphibia, Anura) as revealed by mtDNA gene sequences. Molecular Phylogenetics and Evolution 56:
$259-272$.

Matsui, M., Nishikawa, K., And Yambun, P. 2014a. A new Leptolalax from mountains of Sabah, Borneo (Amphibia, Anura, Megophryidae). Zootaxa 3753: 440-452.

Matsui, M., Zainudin, R., And Nishikawa, K. 2014b. A new species of Leptolalax from Sarawak, western Borneo (Anura: Megophryidae). Zoological Science 31: 773-779.

Oberhummer, E., Barten, C., Schweizer, M., Das, I., HaAs, A., and Hertwig, S. T. 2014. Description of the tadpoles of three rare species of megophryid frogs (Amphibia: Anura: Megophryidae) from Gunung Mulu, Sarawak, Malaysia. Zootaxa 3835: 59-79.

Sмiтн, M. A. 1925. Contributions to the herpetology of Borneo. Sarawak Museum Journal 3: 15-34.

Accepted: 18 June 2015 